\title{
MOLECULAR PHYLOGENETICS OF MORMOLYCA (ORCHIDACEAE: MAXILLARIINAE) BASED ON COMBINED MOLECULAR DATA SETS
}

\author{
Rafael Arévalo* \& Kenneth M. Cameron \\ Department of Botany, University of Wisconsin-Madison, 430 Lincoln Drive, \\ Madison, WI 53706-1381, U.S.A. \\ *Author for correspondence: rafarev@gmail.com
}

\begin{abstract}
The Neotropical orchid genus Mormolyca Fenzl, as currently circumscribed, encompasses a diverse group of ca. 27species. Many of these were included traditionally in Maxillaria sect. Rufescens, when similarity of floral morphology was considered foremost in their classification rather than the evolutionary history of the taxa. In order to begin revising species delimitation and clarifying the evolution and biology of the genus, we present a phylogenetic hypothesis using sequence data from five plastid loci (rpoCl, matK gene and flanking trnK intron, $a t p B-r b c L$ intergenic spacer, and the 3' portion of $y c f 1$ ) and the nuclear ribosomal internal and external transcribed spacers (ITS, ETS). Resulting trees using both Bayesian and parsimony inference are congruent with each other, and generally well resolved. Based on current level of sampling across Maxillariinae, these molecular data support the monophyly of Mormolyca and shed light on the interspecific phylogenetic patterns within the genus. These include an early divergent paraphyletic grade of Mormolyca species successively sister to a clade with at least two definable subclades within. The latter are characterized by two different flower morphologies that are likely related to their pollination systems. Although not all relationships within the genus are fully resolved or supported, these results offer a first glimpse into the phylogeny of a small group of epiphytic orchids characterized by an unusually high level of variable vegetative characters, floral fragrance profiles, and pollination systems.
\end{abstract}

KEY wORDs: Maxillariinae, Mormolyca, molecular phylogenetics, Bayesian inference, Orchidaceae onomy

\section{Introduction}

The orchid subtribe Maxillariinae (subfamily Epidendroideae: tribe Cymbidieae) is one of the most conspicuous and vegetatively diverse groups of Neotropical orchids (Dressler 1993; Whitten 2009). As a result, reconstructing evolutionary relationships among its more than 750 species historically has been challenging (Christenson 2002). However, molecular phylogenetic analyses published by Whitten et al. (2007) using DNA sequences from more than 600 specimens allowed for a new interpretation of the subtribe that has been useful for redefining particular genera (Whitten \& Blanco 2011). Based on wellsupported clades in the gene trees and defined by morphological synapomorphies, several genera of Maxillariinae were recircumscribed by Blanco et al. (2007). One genus in particular, Mormolyca Fenzl, changed significantly. Molecular phylogenetic analyses retrieved a strongly supported clade that included a paraphyletic Mormolyca s.s. sister to a clade composed of species from the previously recognized Maxillaria rufescens complex, with the genus Chrysocycnis embedded within it (Whitten et al. 2007). These now have been transferred into Mormolyca to achieve monophyly of the genus, thereby expanding it from six to ca. 27 species, and increasing the range of floral and vegetative diversity within the group. Mormolyca, therefore, represents another example of the way in which traditional orchid classification systems that have relied almost entirely on floral morphology do not always accurately reflect the evolutionary history of their taxa.

The genus Mormolyca as originally circumscribed by Garay and Wirth (1959) was differentiated from Maxillaria on the basis of morphological characters such as its long inflorescence, absence of a column foot, and moon-shaped viscidium. Species of the Maxillaria rufescens complex (a.k.a. the Rufescens complex) are vegetatively similar to Mormolyca s.s. in their shortly creeping rhizomes with unifoliate pseudobulbs subtended by papery bracts (Carnevali Fernández-Concha et al. 2001), but the inflorescences 
are much shorter. On the opposite side of the spectrum, the two species previously placed in Chrysocycnis are characterized by their elongate, erect rhizomes between scattered unifoliate pseudobulbs (Sweet 1971).

Plants from both Mormolyca s.s. and the former concept of Chrysocycnis have flat open flowers with a tomentose, insect-like labellum and arcuate column (especially pronounced in Chrysocycnis). Given that flowers of $M$. ringens are know to be pollinated by male bees through a syndrome of deceit pseudocopulation (Singer et al. 2004), we expect many or all species of Mormolyca with similar insectiform flowers (Fig. $1 \mathrm{G}, \mathrm{H}, \mathrm{J} \& \mathrm{M})$, to be pollinated by sexual deceit-a pollination system that was made famous over the past century by studies of unrelated terrestrial orchids in Europe, Australia, and South Africa (Stoutamire 1974, 1983; Paulus \& Gack 1990; Schiestl et al. 2003; Johnson \& Morita 2006; van der Niet et al. 2011). In contrast, some of the Mormolyca species transferred from the Rufescens complex have semi-open flowers with a labellum pad of short, glandular trichomes (Fig. 1 A-C, $\mathrm{E}, \mathrm{K}, \mathrm{L}, \mathrm{N}, \mathrm{O}, \mathrm{Q}, \mathrm{R})$, and exhibit a conspicuous diversity of pleasant floral scents (Christenson 2002; Flach et al. 2004; pers. obs.). These orchids are almost certainly not sexually deceptive but instead appear to offer rewards to their pollinators in the form of specialized, nutrientrich trichomes (Davies et al. 2000; Davies \& Turner 2004; Davies \& Stpiczyńska 2012). The remainder of the species from the former Rufescens complex have either resin-secreting or resin-mimic flowers (Davies et al. 2012) with glossy labella (Fig 1. D, F, I, P), and a faint (sometimes absent), sweet, floral scent (personal obs.). These particular examples of highly specialized and varied floral forms indicate that pollinator-mediated selection probably played an important role in the diversification of Mormolyca. Thus, the newly expanded concept of the genus presents an especially appealing group to examine in greater detail from the perspective of taxonomy, systematics, and evolution.

The relationship between Mormolyca s.s. and the Rufescens complex was initially suggested by analyses of anatomical and morphological characters (Atwood \& Mora de Retana 1999; Holtzmeier et al. 1998), and subsequently confirmed by phylogenetic analyses of molecular data (Dathe \& Dietrich 2006; Whitten et al. 2007). However, our knowledge of the evolutionary relationships within the group is still quite limited, as more species need to be incorporated into analyses. These include a handful of recently discovered species (Bogarin \& Pupulin 2010; R. Arevalo and G. Carnevali unpubl. data). Not only is the genus now defined by vegetative rather than floral synapomorphies, but chemical characters related to pollination systems may also be useful for clarifying species boundaries. To understand patterns of diversification within the genus and in order to revise species delimitations that will ultimately lead to a stable classification of these orchids, a thoroughly sampled and well-supported phylogenetic framework is required. In this study we increase the dimensions of previously published molecular data sets by increasing taxon and gene samplings. We also implement alternative methods of molecular phylogenetic analysis (maximum parsimony and Bayesian inference) in an attempt to reconstruct a fully resolved and highly supported molecular phylogeny of Mormolyca that can be used in subsequent evolutionary studies and taxonomic revision of the genus.

\section{Materials and methods}

Taxon sampling - From the ca. 27 species estimated to be in the new broad concept of Mormolyca (Blanco et al. 2007), we sampled 23 species/morphospecies (Table 1). In addition to the 17 used by Whitten et al. (2007), we increased the number of samples and species by targeting missing taxa from areas poorly represented in the original matrices, namely Colombia, Ecuador, and Peru. Our outgroup taxa comprise 36 species from 16 other genera of Maxillariinae (Whitten et al. 2007), including three recently described species new to science (Arévalo et al. 2013). A few specimens could not be identified unequivocally to species; they may represent new species or are elements of highly variable species complexes. These are identified with either the species modifier "c.f." or the name of its putative closest relative or with the abbreviation "sp. nov." after the genus, respectively. Even though our sampling of Mormolyca s.1. is still $26 \%$ incomplete, we are confident that we have included enough representatives of the genus to begin making assertions about the evolutionary relationships among the taxa.

DNA extraction, amplification, and sequencing Once specimens were obtained, plant tissue was 
TABLE 1. Voucher information for taxa used in this study. Herbarium acronyms: $C O L=$ Universidad Nacional de Colombia, Bogotá D.C., Colombia; CR = Museo Nacional de Costa Rica, San José, Costa Rica; FLAS = University of Florida; JBL = Jardín Botánico Lankester, Universidad de Costa Rica, Cartago, Costa Rica; M = Botanische Staatssammlung München, München, Germany; SEL = Marie Selby Botanical Gardens, Sarasota, FL, U.S.A,; QCA = Pontificia Universidad Católica del Ecuador, Quito, Ecuador; SP = Instituto de Botânica, São Paulo, Brazil; UEC = Universidade Estadual de Campinas, Brazil; WIS = University of Wisconsin, Madison, U.S.A.Figure 3. Majority-rule consensus of 7500 trees obtained from Bayesian analysis (GTR + gamma model of evolution) of combined plastid and nuclear DNA regions. Numbers above branches are bootstrap percentages; numbers below branches are Bayesian posterior probabilities. Colored branches indicate the groups discussed in the text. Letter codes following the taxon name, where present, represent the country of provenance: $\mathrm{CLM}=$ Colombia, $\mathrm{COS}=$ Costa Rica, $\mathrm{ECU}=\mathrm{Ecuador}, \mathrm{HON}=$ Honduras, PAN=Panama, $\mathrm{PER}=$ Peru, PUE=Puerto Rico.

\begin{tabular}{|c|c|c|c|c|}
\hline & Taxon & $\begin{array}{l}\text { Collector and } \\
\text { number }\end{array}$ & Source & Herbarium \\
\hline 1 & $\begin{array}{l}\text { Brasiliorchis picta (Hook.) R.B.Singer, S.Koehler } \\
\text { \& Carnevali }\end{array}$ & Whitten 2755 & Brazil, cult. & FLAS \\
\hline 2 & $\begin{array}{l}\text { Brasiliorchis schunkeana (Campacci \& Kautsky) } \\
\text { R.B.Singer, S.Koehler \& Carnevali }\end{array}$ & Whitten 1992 & Brazil, cult. & FLAS \\
\hline 3 & Bifrenaria tetragona (Lindl.) Schltr. & Whitten 93156 & Brazil & FLAS \\
\hline 4 & Camaridium carinulatum (Rchb.f.) M.A.Blanco & Arévalo 932 & Colombia & $\mathrm{COL}$ \\
\hline 5 & Camaridium ochroleucum Lindl. & Gerlach 2003-3648 & Brazil & M \\
\hline 6 & $\begin{array}{l}\text { Christensonella ferdinandiana (Barb.Rodr.) } \\
\text { Szlach., Mytnik, Górniak \& Smiszek }\end{array}$ & Koehler 0089 & Brazil & SP \\
\hline 7 & Christensonella nardoides (Kraenzl.) Szlach. & Whitten 2502 & Ecuador, cult. Ecuagenera & FLAS \\
\hline 8 & Cryptocentrum peruvianum (Cogn.) C.Schweinf. & Whitten 2322 & Ecuador & FLAS \\
\hline 9 & Cryptocentrum sp. & Arévalo 931 & Colombia & $\mathrm{COL}$ \\
\hline 10 & Cyrtidiorchis alata (Ruiz \& Pav.) Rauschert & Whitten 2932 & Ecuador, cult. & FLAS \\
\hline 11 & $\begin{array}{l}\text { Cyrtidiorchis rhomboglossa (F.Lehm. \& Kraenzl.) } \\
\text { Rauschert }\end{array}$ & Giraldo 17 & Colombia & $\mathrm{COL}$ \\
\hline 12 & Eriopsis biloba Lindl. & Whitten 3153 & Ecuador & QCA \\
\hline 13 & Heterotaxis villosa (Barb.Rodr.) F.Barros & Arévalo 902 & Colombia & $\mathrm{COL}$ \\
\hline 14 & Heterotaxis violaceopunctata (Rchb.f.) F.Barros & Whitten 2294 & Brazil, cult. & FLAS \\
\hline 15 & Inti bicallosa (Rchb.f.) M.A.Blanco & Whitten 2636, & Panama & FLAS \\
\hline 16 & Inti chartacifolia (Ames \& C.Schweinf.) M.A.Blanco & Whitten 2752 & cult. & FLAS \\
\hline 17 & $\begin{array}{l}\text { Mapinguari auyantepuiensis (Foldats) Carnevali } \\
\text { \& R.B.Singer }\end{array}$ & Whitten 2347 & Ecuador & FLAS \\
\hline 18 & $\begin{array}{l}\text { Mapinguari longipetiolatus (Ames \& C.Schweinf.) } \\
\text { Carnevali \& R.B.Singer }\end{array}$ & $\begin{array}{l}\text { Atwood \& Whitten } \\
5075\end{array}$ & Costa Rica & SEL \\
\hline 19 & Maxillaria farinosa Arévalo \& Christenson, sp. nov. & Arévalo 734 & Colombia & $\mathrm{COL}$ \\
\hline 20 & Maxillaria splendens Poepp. \& Endl. & Koehler 0144 & Brazil, cult. & UEC \\
\hline 21 & $\begin{array}{l}\text { Maxillaria tenebrifolia Arévalo \& Christenson, sp. } \\
\text { nov. }\end{array}$ & Arévalo 454 & Colombia & $\mathrm{COL}$ \\
\hline 22 & $\begin{array}{l}\text { Maxillariella procurrens (Lindl.) M.A.Blanco \& } \\
\text { Carnevali }\end{array}$ & Whitten 2397 & Ecuador, cult. & FLAS \\
\hline \multirow[t]{2}{*}{23} & \multirow[t]{2}{*}{ Mormolyca cf. acutifolia (Lindl.) M.A.Blanco } & 1: Arévalo 1071 & Colombia, cult. Colomborquideas & WIS \\
\hline & & 2: Giraldo 44 & Colombia & COL \\
\hline 24 & $\begin{array}{l}\text { Mormolyca cf. aureoglobula (Christenson) } \\
\text { M.A.Blanco }\end{array}$ & Arévalo 1069 & $\begin{array}{l}\text { Colombia, cult. Orquídeas del } \\
\text { Valle }\end{array}$ & WIS \\
\hline 25 & Mormolyca chacoensis (Dodson) M.A.Blanco & Arévalo 947 & Perú, cult., Agroriente Viveros & $\mathrm{COL}$ \\
\hline
\end{tabular}


TABLE 1. Continued.

\begin{tabular}{|c|c|c|c|c|}
\hline 26 & Mormolyca culebrica Bogarín \& Pupulin & Whitten 2650 & Pánama, cult. & FLAS \\
\hline \multirow[t]{2}{*}{27} & \multirow{2}{*}{$\begin{array}{l}\text { Mormolyca dressleriana (Carnevali \& J.T.Atwood) } \\
\text { M.A.Blanco }\end{array}$} & 1: Arévalo 1066 & Pánama, cult. & WIS \\
\hline & & 2. Arévalo 1065 & Costa Rica, cult. & WIS \\
\hline 28 & Mormolyca fumea Bogarín \& Pupulin & Bogarín 5729 & Costa Rica & $\mathrm{CR}$ \\
\hline 29 & Mormolyca gracilipes (Schltr.) Garay \& Wirth & Arévalo 1061 & $\begin{array}{l}\text { Colombia, cult., Orquídeas del } \\
\text { Valle }\end{array}$ & WIS \\
\hline \multirow[t]{2}{*}{30} & \multirow{2}{*}{$\begin{array}{l}\text { Mormolyca hedwigiae (Hamer \& Dodson) } \\
\text { M.A.Blanco }\end{array}$} & 1: Koehler 0314 & Guatemala, cult. & ESA \\
\hline & & 2: Arévalo 1065 & Honduras, cult. & WIS \\
\hline \multirow[t]{2}{*}{31} & \multirow{2}{*}{$\begin{array}{l}\text { Mormolyca moralesii (Carnevali \& J.T.Atwood) } \\
\text { M.A.Blanco }\end{array}$} & 1: Bogarín 3826 & Costa Rica & $J B L$ \\
\hline & & 2: Bogarín 4139 & Costa Rica & JBL \\
\hline 32 & Mormolyca peruviana C.Schweinf. & Whitten 2497 & Ecuador, cult. & FLAS \\
\hline 33 & Mormolyca polyphylla Garay \& Wirth & Arévalo 950 & Ecuador, cult. Ecuagenera & $\mathrm{COL}$ \\
\hline 34 & $\begin{array}{l}\text { Mormolyca pudica (Carnevali \& J.L.Tapia) } \\
\text { M.A.Blanco }\end{array}$ & Arévalo 1068 & Puerto Rico & WIS \\
\hline \multirow[t]{2}{*}{35} & \multirow[t]{2}{*}{ Mormolyca richii (Dodson) M.A.Blanco } & 1: Whitten 2362 & Ecuador, cult. & FLAS \\
\hline & & 2: Arévalo 1064 & Ecuador, cult. & WIS \\
\hline 36 & Mormolyca ringens (Lindl.) Gentil & Arévalo 1062 & $\begin{array}{l}\text { Colombia, cult. Orquídeas del } \\
\text { Valle }\end{array}$ & WIS \\
\hline \multirow[t]{6}{*}{37} & \multirow[t]{6}{*}{ Mormolyca rufescens (Lindl.) M.A.Blanco } & 1: Arévalo 1073 & $\begin{array}{l}\text { U.S.A., cult. Marie Selby } \\
\text { Botanical Gardens }\end{array}$ & WIS \\
\hline & & 2: Arévalo 941 & Perú, cult., Agroriente Viveros & WIS \\
\hline & & 3: Arévalo 1076 & $\begin{array}{l}\text { U.S.A., cult. Marie Selby } \\
\text { Botanical Gardens }\end{array}$ & WIS \\
\hline & & 4: Arévalo 1075 & $\begin{array}{l}\text { U.S.A., cult. Marie Selby } \\
\text { Botanical Gardens }\end{array}$ & WIS \\
\hline & & 5: Arévalo 942 & Perú, cult., Agroriente Viveros & $\mathrm{COL}$ \\
\hline & & 6: Arévalo 943 & Perú, cult., Agroriente Viveros & $\mathrm{COL}$ \\
\hline 38 & $\begin{array}{l}\text { Mormolyca sanantonioensis (Christenson) } \\
\text { M.A.Blanco }\end{array}$ & Arévalo 1070 & $\begin{array}{l}\text { Colombia, cult. Orquídeas del } \\
\text { Valle }\end{array}$ & WIS \\
\hline 39 & Mormolyca schlimii (Linden \& Rchb.f.) M.A.Blanco & Giraldo 763 & Colombia & $\mathrm{COL}$ \\
\hline 40 & Mormolyca schweinfurthiana Garay \& Wirth & Arévalo 956 & Ecuador, cult. Ecuagenera & $\mathrm{COL}$ \\
\hline 41 & Mormolyca suareziorum (Dodson) M.A.Blanco & Arévalo 945 & Perú, cult., Agroriente Viveros & $\mathrm{COL}$ \\
\hline 42 & Mormolyca cf. suareziorum (Dodson) M.A.Blanco & Whitten 2758 & Ecuador, cult. & FLAS \\
\hline \multirow[t]{3}{*}{43} & \multirow[t]{3}{*}{$\begin{array}{l}\text { Mormolyca cf. tenuibulba (Christenson) } \\
\text { M.A.Blanco }\end{array}$} & 1: Arévalo 878 & Colombia & $\mathrm{COL}$ \\
\hline & & 2: Arévalo 951 & Ecuador, cult., Ecuagenera & $\mathrm{COL}$ \\
\hline & & 3: Arévalo 1072 & Colombia, cult. Colomborquideas & WIS \\
\hline 44 & Mormolyca sp. nov. A & Arévalo 1063 & $\begin{array}{l}\text { U.S.A., cult., Marie Selby } \\
\text { Botanical Gardens }\end{array}$ & WIS \\
\hline 45 & Mormolyca sp. nov. B & Blanco 3108 & Ecuador, cult. & FLAS \\
\hline \multirow[t]{3}{*}{46} & \multirow[t]{3}{*}{ Mormolyca sp. nov. C } & 1: Arévalo 1074 & $\begin{array}{l}\text { Colombia, cult. } \\
\text { Colomborquídeas }\end{array}$ & WIS \\
\hline & & 2: Arévalo 939 & Perú, cult., Agroriente Viveros & $\mathrm{COL}$ \\
\hline & & 3: Arévalo 953 & Perú, cult., Agroriente Viveros & $\mathrm{COL}$ \\
\hline
\end{tabular}


TABLe 1. Continued.

\begin{tabular}{l|l|l|l|l}
\hline 47 & Nitidobulbon nasutum (Rchb.f.) Ojeda \& Carnevali & Whitten 1869 & Ecuador & FLAS \\
\hline 48 & $\begin{array}{l}\text { Nitidobulbon proboscideum (Rchb.f.) Ojeda \& } \\
\text { Carnevali }\end{array}$ & $\begin{array}{l}\text { Atwood \& Whitten } \\
5056\end{array}$ & Venezuela & SEL \\
\hline 49 & Ornithidium montezumae Arévalo \& Christenson & Arévalo 674 & Colombia & COL \\
\hline 50 & Ornithidium cf. semiscabrum Lindl. & Arévalo 588 & Colombia & COL \\
\hline 51 & Ornithidium aggregatum (Kunth) Rchb.f. & Arévalo 623 & Colombia & COL \\
\hline 52 & Pityphyllum saragurense (Dodson) Whitten & Whitten 3084 & Ecuador, cult. & QCA \\
\hline 53 & Pityphyllum antioquiense Schltr. & Whitten 2473 & Ecuador, cult. & FLAS \\
\hline 55 & Rhetinantha acuminata (Lindl.) M.A.Blanco & Whitten 2698 & Ecuador & FLAS \\
\hline 56 & Shetinantha notylioglossa (Rchb.f.) M.A.Blanco & Koehler 0033 & Brazil & UEC \\
\hline 57 & Sauvetrea laevilabris (Lindl.) M.A.Blanco & Whitten 2358 & Ecuador, cult. & FLAS \\
\hline 58 & Trigonidium egertonianum Bateman ex Lindl. & Arévalo 1060 & cult. & FLAS \\
\hline 59 & Trigonidium obtusum Lindl. & Whitten 2997 & cult. & WIS \\
\hline
\end{tabular}

preserved in silica gel, and genomic DNA was extracted using the DNeasy Plant Mini Kit (Qiagen, Valencia, California, U.S.A.). Living specimens were documented with detailed photographs prior to being pressed for herbarium vouchers. When possible, flowers were collected and preserved in FAA for micro-morphological assessment.

For each specimen we attempted to sequence the plastid matK gene and flanking $\operatorname{trnK}$ intron, the $a t p B-r b c L$ intergenic spacer, the $r p o C l$ gene, and the downstream (3') portions of $y c f 1$, along with the nuclear ribosomal ITS and ETS regions. DNA amplification and sequencing was carried out following published primers and methods, with modifications when necessary $($ matK + trnK, atpB-rbcL, rpoCl and ITS from Whitten et al. 2007; ycf1 from Neubig et al. 2009; ETS from Monteiro et al. 2010). Electropherograms were assembled and edited using Geneious Pro 5.0.3 (Drummond et al. 2010); alignments were generated using MUSCLE (Edgar 2004) and adjusted by eye using MacClade (Maddison \& Maddison 2005).

Data analysis-Phylogenetic inference methods included maximum parsimony (MP) and Bayesian inference $(\mathrm{BI})$. We performed combined analysis with ITS + ETS (nrDNA), all four plastid regions (cpDNA), and finally with all regions (total DNA). MP analyses were performed in PAUP* 4.10b (Swofford 2002) with Fitch parsimony as the optimality criterion (unordered characters, equal weights; Fitch 1971),
ACCTRAN optimization, and gaps treated as missing data. The heuristic search strategy consisted of 5000 random-addition replicates of branch swapping by subtree-pruning-regrafting (SPR), saving multiple trees (MULTREES), and holding five trees at each step. The resulting trees were then used as starting trees for tree-bisection-reconnection swapping (TBR). Levels of support were estimated from 1000 bootstrap replicates, using TBR swapping for five randomaddition replicates per bootstrap replicate. Parsimony ratchet search strategy for finding shortest trees was also performed with the program PAUPRat (Sikes \& Lewis 2001). The software package MRBAYES v3.2.1 (Ronquist et al. 2012) was used for BI analyses. Tree searches were performed assuming single and multiple models of sequence evolution for each partition, following the "Akaike information criterion" as implemented in JModeltest (Posada 2008). For each analysis, Markov chain Monte Carlo (MCMC) searches were made for 10 million generations, sampling every 1000 generations, with a burn-in of $25 \%$ and chains heated to 0.07 (increasing the frequency of data swapping between chains).

\section{Results}

Statistics associated with MP analyses of cpDNA, nrDNA, and total DNA data sets are summarized in Table 2. Analysis of both cpDNA and nrDNA data sets strongly support the monophyly of Mormolyca, 
TABLE 2. Features of DNA data sets used in this study. CI = consistency index; RI = retention index. Percentages calculated in relation to aligned length.

\begin{tabular}{l|l|l|l|l|l|l|l|l}
\hline Data set & \multicolumn{1}{|c|}{$\begin{array}{c}\text { No. of } \\
\text { ingroup taxa }\end{array}$} & \multicolumn{1}{|c|}{$\begin{array}{c}\text { Aligned } \\
\text { length }\end{array}$} & $\begin{array}{c}\text { No. of variable } \\
\text { characters }\end{array}$ & $\begin{array}{c}\text { No. of parsimony- } \\
\text { informative } \\
\text { characters }\end{array}$ & $\begin{array}{c}\text { No. of most } \\
\text { parsimonious } \\
\text { trees }\end{array}$ & $\begin{array}{c}\text { Tree } \\
\text { length }\end{array}$ & $\mathbf{C l}$ & $\mathbf{R I}$ \\
\hline nrDNA & 38 & 1368 & $546(39.9 \%)$ & $301(22 \%)$ & 126,660 & 1129 & 0.637 & 0.716 \\
\hline cpDNA & 38 & 7242 & $1254(17.3 \%)$ & $521(7.2 \%)$ & 88,329 & 2155 & 0.650 & 0.706 \\
\hline totalDNA & 38 & 8610 & $1801(20.9 \%)$ & $822(9.5 \%)$ & 8353 & 3373 & 0.629 & 0.688 \\
\hline
\end{tabular}

although relationships within the genus differ in the absence of strongly supported clades in the nrDNA analysis (trees not shown). By comparison, the total DNA matrix offered the highest level of resolution among all genera and within Mormolyca, as assessed by bootstrap support. The strict consensus tree from MP analysis of the total DNA data set is presented in Fig. 2. For BI analysis, the model-based estimate based on the cpDNA regions produced a tree with higher levels of support when compared to the nrDNA tree (trees not shown). Consensus trees from BI and MP were similar, but the Bayesian tree was more highly resolved within Mormolyca. This is the tree upon which our discussion will follow (Fig. 3).

Placement of the recently described species (Maxillaria farinosa, M. tenebrifolia, and Ornithidium montezumae) within their respective lineage in the overall tree confirm their assigned genera (Fig. 2). Mormolyca s.l. forms a monophyletic group with strong support. Taxa within the genus can be divided into three clusters (showed with color branches on tree) for the sake of further discussion: a grade of early divergent species and two clades (Fig. 2).

Mormolyca s.s. species (green branches on tree) are the earliest extant lineages to diverge from the genus, represented here by $M$. polyphyla, $M$. peruviana, M. schweinfurthiana, M. gracilipes, and $M$. ringens, ending with $M$. schlimii, which is sister to the single large clade containing all members of the former Rufescens complex (Fig. 2). Topographically, this clade, consists of clade I (purple branches) with weak support (BP 69\%, PP 1.0) but fully resolved, and clade II (orange branches) that is not fully resolved.

\section{Discussion}

This study confirms the inclusion of species from the Maxillaria rufescens complex and Chrysocycnis species within Mormolyca (Blanco et al. 2007, Whitten et al. 2012). In general, as now defined, Mormolyca s.l. can be recognized by the following combination of characters: unifoliate pseudobulbs subtended by a nonfoliaceous (papery) sheaths (except for M. polyphylla, which has elongated pseudobulbs subtended by more than one sheath and up to three apical leaves), the single-flowered, erect inflorescence produced from the older parts of the rhizome (rather than from the terminal growth), perianth parts that lack fibers, and the clavate, arcuate column (Blanco et al. 2007). Distribution of the genus ranges from southern Mexico in the north to Bolivia and northern Brazil in the south, with plants typically found in forests at elevations from sea level to 1900 m.a.s.1. (based on gathered data from herbarium specimens). One taxon, M. pudica, is apparently restricted to the Greater Antilles (Carnevali FernandezConcha et al. 2001). A weak geographic pattern can be detected in the phylogenetic reconstruction, with most of the early-diverging species restricted to the southern part of the range, (i.e., from Peru, Ecuador, and Colombia), whereas the more derived clades have a more northern distribution, reaching all the way to southern Mexico.

The consecutively early-diverging and paraphyletic taxa are represented here by most species of Mormolyca s.s. and M. schlimii. All are morphologically similar, particularly in their flowers (i.e. absence of a column foot, the insectiform labellum, and the prominent arcuate column). Unfortunately, our study did not include M. aurorae or M. fuchsii, which are known only from the type specimens, and M. lehmanii, for which we were unable to obtain samples. We would expect these species to be positioned in this part of the tree as well. The appearance of $M$. gracilipes and M. schweinfurthiana as sister species may reflect a misidentification of one of the samples and/or poor alpha-taxonomy. These two species are similar in form, and the two names are often incorrectly applied. We 


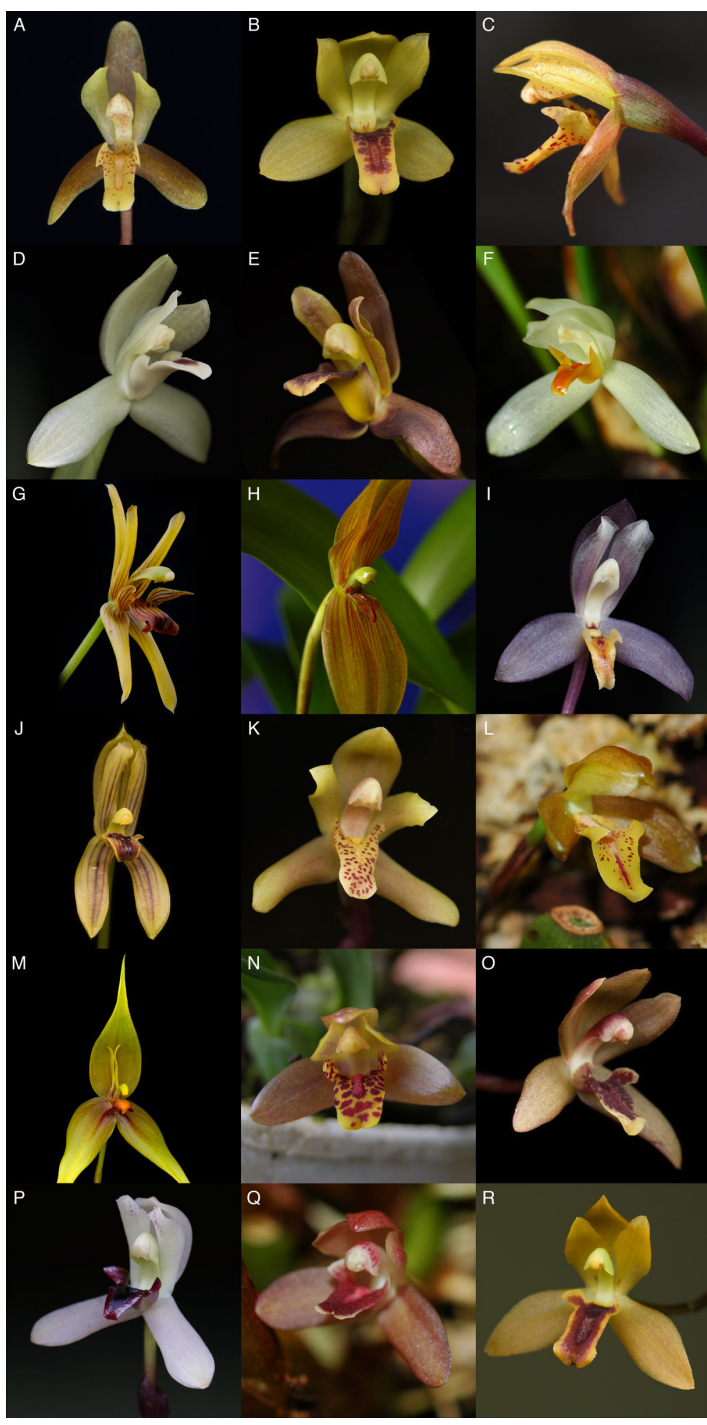

Figure 1. A. Mormolyca acutifolia; B. M. aureoglobula; C. M. cf. chacoensis; D. M. culebrica; E. M. dressleriana; F. M. hedwigiae; G. M. peruviana; H. M. polyphylla; I. $M$. richii; J. M. ringens; K. M. rufescens; L. M. sanantonioensis; M. M. schweinfurthiana; N. M. suareziorum; O. M. tenuibulba; P. M. sp. nov. A; Q. M. sp. nov. B; R. M. sp. nov. C. All photos by R. Arévalo, except J \& M by D. Bogarín.

suspect that they may, in fact, be describing the same species. However, more material including the type material needs to be examined to make a conclusive decision regarding their taxonomy.

Looking at the species distribution within the larger clade that groups the entire Rufescens complex, patterns seem to emerge. Although there is only weak bootstrap support (BS 69\%, PP 1.0) for this group, species with a glossy labellum cluster together. Some of these secrete small quantities of resin on the labellum and are thought to mimic taxa that produce lipoidal rewards (Davies et al. 2012; Arévalo, unpubl. data). This clade includes one of the new species that was found as a result of this study (Mormolyca sp. nov. A), which is sister to the rest of the clade consisting of $M$. richii, $M$. hedwigiae, $M$. culebrica, and $M$. fumea. The latter, which is not recognized by the World Checklist of Selected Plant Families (Govaerts et al. 2011) and considered a synonym of $M$. aureoglobula, appears as a distinct branch sister to $M$. culebrica in our analyses. This result indicates that it probably does deserve to be treated as a distinct species.

The remaining Mormolyca species from the former Rufescens complex, characterized by their semi-open, fragrant flowers with a labellum pad of short, glandular trichomes (Flach et al. 2004; pers. obs.), also cluster together. Species delimitation in this group has been difficult historically, with nearly every species of the complex included at one point either in a broad concept of either Mormolyca rufescens (Lindl.) Blanco, or $M$. acutifolia (Lindl.) Blanco. Large- flowered specimens with conspicuous fragrances are usually associated with $M$. rufescens, whereas all small-flowered entities are usually considered to be related to M. acutifolia. A factor contributing to this taxonomic confusion is the fact that M. acutifolia (Lindl.) Blanco is poorly defined. Other than the type specimen itself, there is only a vague description from Lindley (1839) and a single drawing of the flower labellum found with the holotype.

Also, within this cluster we find $M$. dressleriana as sister to a group of species in which relationships and alpha-taxonomy are still imprecise. This group reunites what we are considering $M$. acutifolia along with some entities originally related to the species and now segregated (i.e. M. pudica, M. aureoglobula, M. sanantonioensis, M. moralesii). It also contains multiple individuals of $M$. tenuibulba, a species characterized by having ascending rhizomes with long pseudobulbs and coconut-scented flowers. Accessions of this species are not monophyletic, which we believe may be due to incomplete data sampling. A new morphologically distinct species 


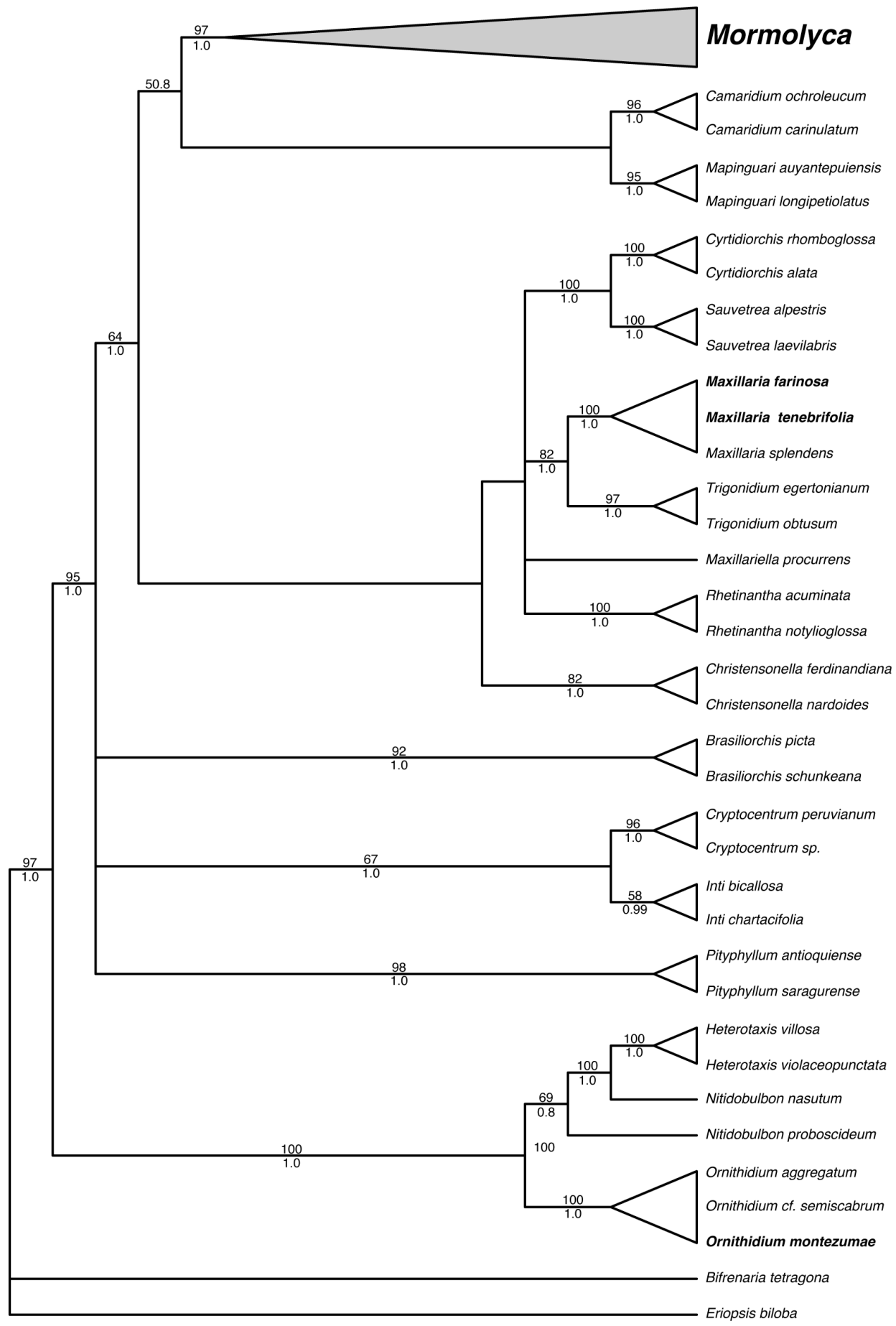

FIGURE 2. Strict consensus tree from the 8353 equally most parsimonious trees after maximum parsimony analysis of the combined (plastid and nuclear) data matrix. Numbers above branches are bootstrap percentages; numbers below branches are posterior probabilities for clades estimated by the proportion of occurrence in the tree set from Bayesian analysis. Taxa in bold correspond to species recently described by the authors. 


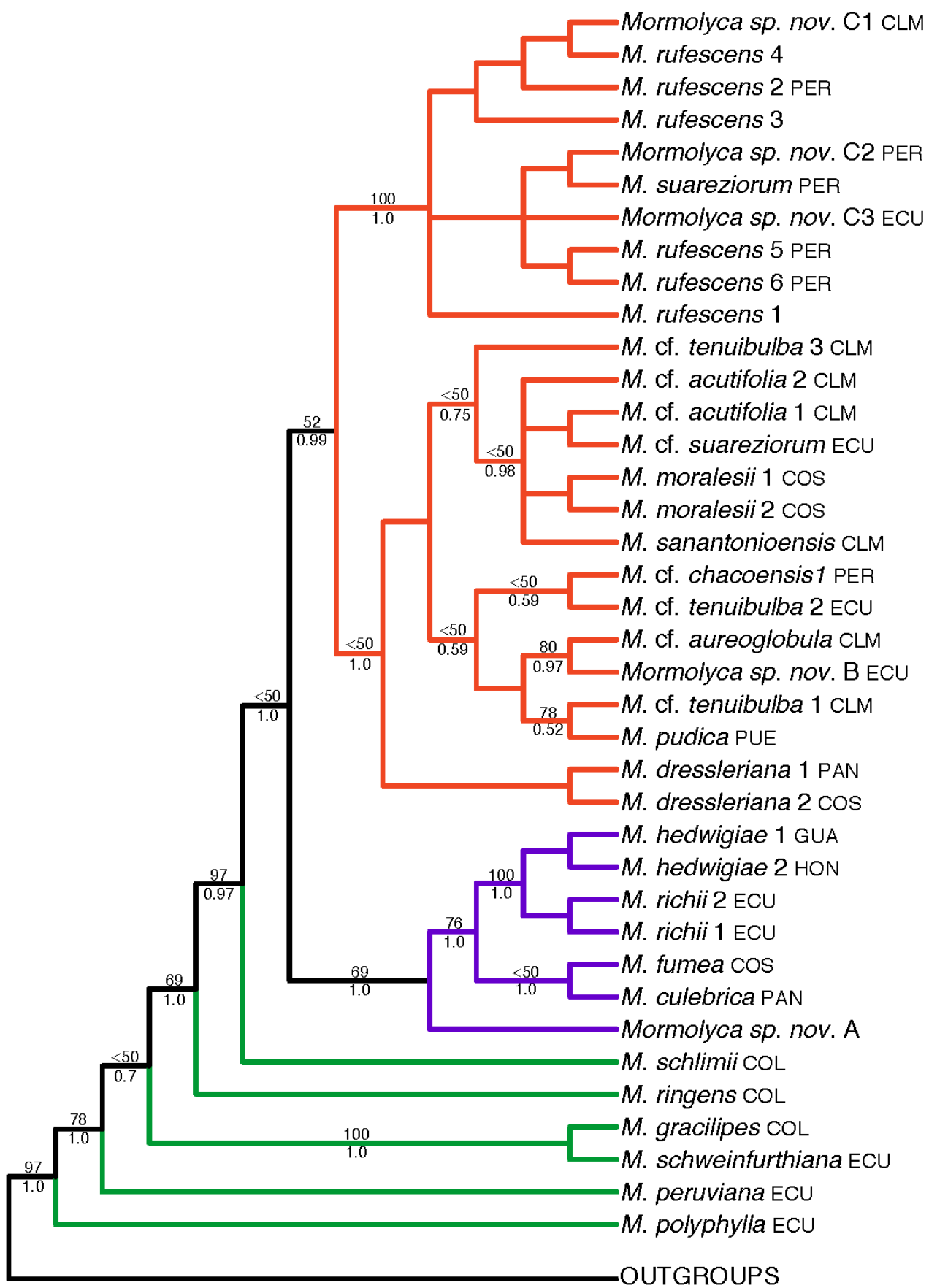

FIGURE 3. Majority-rule consensus of 7500 trees obtained from Bayesian analysis (GTR + gamma model of evolution) of combined plastid and nuclear DNA regions. Numbers above branches are bootstrap percentages; numbers below branches are Bayesian posterior probabilities. Colored branches indicate the groups discussed in the text. Letter codes following the taxon name, where present, represent the country of provenance: CLM $=$ Colombia, $\mathrm{COS}=\mathrm{Costa}$ Rica, $\mathrm{ECU}=$ Ecuador, $\mathrm{HON}=$ Honduras, $\mathrm{PAN}=$ Panama, $\mathrm{PER}=$ Peru, $\mathrm{PUE}=$ Puerto Rico. 
of Mormolyca previously recognized (G. Carnevali, pers. comm. 2008), also appears here (Mormolyca sp. nov. B). In general, the topology recovered for this part of the tree indicates that species boundaries need to be better defined in this group. A revision is currently in progress.

Finally, we recovered a well-supported clade that includes all large-flowered plants associated with M. rufescens, as well as the small-flowered species M. suareziorum, along with accessions of what we are considering another new species of Mormolyca (Mormolyca sp. nov. C) from three different locations. We included multiple samples of $M$. rufescens that vary in flower color pattern, a character often used to segregate new species of Mormolyca (e.g. Christenson 2010), to test taxonomic hypotheses of reciprocal monophyly. Unfortunately, precise relationships among these accessions are unresolved in our analyses, and so issues of species delimitations will require further study.

In summary, despite our efforts to resolve phylogenetic relationships more fully within Mormolyca, more work still remains to be done. Species delimitation in this genus is difficult, but we feel strongly that variation in flower color should be reconsidered or even disregarded as a character used to segregate species. Given the importance of flower micro-morphology in their pollination systems, detailed morphological analyses are currently underway in the search for unambiguous synapomorphies. This is our first attempt to reconstruct a phylogeny of Mormolyca, and we are confident that the addition of genetic data from more variable loci such as the low-copy nuclear gene PhyC (Russell et al. 2010), as well as micromorphological characters will help us achieve a better estimate of relationships within the genus. Evolutionary processes that underlie the patterns of variation and specialization exhibited by this group of plants remain to be investigated. To address these challenges and utilize Mormolyca as a model system for understanding orchid pollinator evolution within Neotropical epiphytic Orchidaceae, we expect eventually to couple these molecular phylogenetic data with floral morphology and patterns of volatile production to assess the role of evolving flower form and function in the process of orchid speciation.

\section{LiteRATURE CITED}

Arévalo, R., K. Cameron \& E. Christenson. 2013. Three new species of Ornithidium and Maxillaria (Maxillariinae) from Colombia: recent discoveries from the Cordillera Occidental of the Colombian Andes. Orchids 82: 44-48.

Atwood, J.T. \& D.E. Mora de Retana. 1999. Flora Costaricensis family \#39 Orchidaceae: tribe Maxillarieae: subtribes Maxillariinae and Oncidiinae. Fieldiana, Bot., n.s. 40: 1-182.

Blanco, M.A., G. Carnevalli, W.M. Whitten, R.B. Singer, S. Koehler, N.H. Williams, I. Ojeda, K.M. Neubig \& L. Endara. 2007. Generic realignments in Maxillariinae (Orchidaceae). Lankesteriana 7: 515-537.

Bogarín, D. \& F. Pupulin. 2010. Two new species of Mormolyca from Costa Rica and Panama. Orchid Dig. 74: 427-47.

Carnevali Fernández-Concha, G., J.L. Tapia Muñoz \& M. Gómez-Juárez. 2001. A synopsis of the Maxillaria rufescens complex in Mexico, Central America, and the Greater Antilles. Brittonia 53: 454-465.

Christenson, E.A. 2002. Maxillaria, an overview. Pp. 279-290 in: Proceedings of the 16th World Orchid Conference (ed. J. Clark, W. Elliott, G. Tingley \& J. Biro). Vancouver Orchid Society, Richmond, British Columbia, Canada.

Christenson, E.A. 2010. A showy new species of Maxillaria (Orchidaceae) from Bolivia. Richardiana 10: 94-98.

Dathe, S. \& D.H. Dietrich. 2006. Comparative molecular and morphological studies in selected Maxillariinae orchids. Willdenowia 36: 89-102.

Davies, K.L. \& M. Stpiczyńska. 2012. Comparative anatomy of resin-secreting and putative resin-mimic species of Maxillaria s.l. (Orchidaceae: Maxillariinae). Bot. J. Linn. Soc. 170: 405-435.

Davies, K.L. \& M.P. Turner. 2004. Morphology of floral papillae in Maxillaria Ruiz \& Pav. (Orchidaceae). Ann. Bot. 93: 75-86.

Davies, K. L., C. Winters \& M.P. Turner. 2000. Pseudopollen: its structure and development in Maxillaria (Orchidaceae). Ann. Bot. 85: 887-895.

Dressler, R.L. 1993. Phylogeny and classification of the orchid family. Dioscorides Press, Portland, Oregon.

Drummond, A.J., B. Ashton, S. Buxton, M. Cheung, A. Cooper, J. Heled, M. Kearse, R. Moir, S. Stones-Havas, S. Sturrock, T. Thierer \& A. Wilson. 2010. Geneious v5.1, Available from http://www.geneious.com.

Edgar, R.C. 2004. MUSCLE: multiple sequence alignment with high accuracy and high throughput. Nucleic Acids Res. 32:1792-1797.

Fitch, W.M. 1971. Toward defining the course of evolutionminimum change for a specific tree topology. Syst. Zool. 20: 406-416. 
Flach, A., R.C. Dondon, R.B. Singer, S. Koehler, E. Amaral Maria do Carmo \& A.J. Marsaioli. 2004. The chemistry of pollination in selected Brazilian Maxillariinae orchids: floral rewards and fragrance. J. Chem. Ecol. 30: 1045-1056.

Garay, L.A. \& M. Wirth. 1959. On the genera Mormolyca Fenzl and Cyrtoglottis Schltr. Canad. J. Bot. 37: 479490.

Govaerts, R., J. Dransfield, S.F. Zona, D.R. Hodel \& A. Henderson. 2011. World Checklist of Orchidaceae. Facilitated by the Royal Botanic Gardens, Kew. Published on the Internet; http://apps.kew.org/wcsp/ Retrieved 2013-01-22.

Holtzmeier, M.A., W.L. Stern \& W.S. Judd. 1998. Comparative anatomy and systematics of Senghas's cushion species of Maxillaria (Orchidaceae). Bot. J. Linn. Soc. 127: 43-82.

Huelsenbeck, J.P. \& F. Ronquist. 2001. MRBAYES: Bayesian inference of phylogeny. Bioinformatics 17: 754-755.

Johnson, S.D. \& S. Morita. 2006. Lying to Pinocchio: floral deception in an orchid pollinated by long-proboscid flies. Bot. J. Linn. Soc. 152: 271-278.

Lindley, J. 1839. Maxillaria acutifolia. In J. Lindley (ed.), Edwards's Botanical Register, t. 92. London.

Maddison, D.R. \& W.P. Maddison. 2005. MacClade 4: analysis of phylogeny and character evolution. Sinauer Associates, Sunderland, Massachusetts.

Monteiro, S.H., A. Selbach-Schnadelbach, R.P. de Oliveira \& C. van den Berg. 2010. Molecular phylogenetics of Galeandra (Orchidaceae: Catasetinae) based on plastid and nuclear DNA sequences. Syst. Bot. 35: 476-486.

Neubig, K., W.M. Whitten, B. Carlsward, M. Blanco, L. Endara, N. Williams \& M. Moore. 2009. Phylogenetic utility of $y c f 1$ in orchids: a plastid gene more variable than matK. P1. Syst. Evol. 277: 75-84.

Paulus, H.F. \& C. Gack. 1990. Pollinators as prepollinating isolation factors: evolution and speciation in Ophrys (Orchidaceae). Israel J. Bot. 39: 43-79.

Posada, D. 2008. jModelTest: phylogenetic model averaging. Molec. Biol. Evol. 25: 253-256.

Ronquist, F. \& J.P. Huelsenbeck. 2003. MRBAYES 3: Bayesian phylogenetic inference under mixed models. Bioinformatics 19: 1572-1574.

Russell, A., R. Samuel, V. Klejna, M. Barfuss, B. Rupp
\& M. W. Chase. 2010. Reticulate evolution in diploid and tetraploid species of Polystachya (Orchidaceae) as shown by plastid DNA sequences and low-copy nuclear genes. Ann. Bot. 106: 37-56.

Schiestl, F.P., R. Peakall, J.G. Mant, F. Ibarra, C. Schulz, S. Franke \& W. Francke. 2003. The chemistry of sexual deception in an orchid-wasp pollination system. Science 302: 437-438.

Sikes, D.S. \& P.O. Lewis. 2001. Beta software, version 1. PAUPRat: PAUP* implementation of the parsimony ratchet. Distributed by the authors. Department of Ecology and Evolutionary Biology, University of Connecticut, Storrs, Connecticut.

Singer, R.B., A. Flach, S. Koehler, A.J. Marsaioli \& M.C.E. Aamaral. 2004. Sexual mimicry in Mormolyca ringens (Lindl.) Schltr. (Orchidaceae: Maxillariinae). Ann. Bot. 93: 755-762.

Stoutamire, W.P. 1974. Australian terrestrial orchids, thynnid wasps and pseudocopulation. Amer. Orchid. Soc. Bull. 43: 13-18.

Stoutamire, W.P. 1983. Wasp-pollinated species of Caladenia (Orchidaceae) in south western Australia. Austral. J. Bot. 31: 383-394.

Sweet, H.R. 1971. Orquídeas Andinas poco conocidas V. Chrysocycnis Linden \& Rchb.f.. Orquideología 6: 3-10.

Swofford, D.L. 2002. PAUP*. Phylogenetic analysis using parsimony (*and other methods). Version 4. Sinauer, Sunderland, Massachusetts.

van der Niet, T., D.M. Hansen \& S.D. Johnson. 2011. Carrion mimicry in a South African orchid: flowers attract a narrow subset of the fly assemblage on animal carcasses. Ann. Bot. 107: 981-992.

Whitten, W.M. 2009. Subtribe Maxillariinae. Pp. 119-123 in: Genera orchidacearum Vol. 5. Epidendroideae (Part two) (ed. A.M. Pridgeon, P.J. Cribb, M.W. Chase \& F.N. Rasmussen). Oxford University Press, Oxford.

Whitten, W.M. \& M.A. Blanco. 2011. Defining generic limits in Maxillaria. A return to the orchidaceous mine. Orchids 80: 104-113.

Whitten, W.M., M.A. Blanco, N.H. Williams, S. Koehler, G. Carnevali, R.B. Singer, L. Endara \& K.M. Neubig. 2007. Molecular phylogenetics of Maxillaria and related genera (Orchidaceae: Cymbidieae) based on combined molecular data sets. Amer. J. Bot. 94: 18601889. 